\title{
Doctors and torture: an experience as a prisoner
}

\author{
Alfredo Jadresic Royal East Sussex Hospital, Hastings, Sussex
}

\section{Editor's note}

Drfadresic was taken prisoner following the military coup in Chile in 1973. While under arrest he was called upon to assist the military doctor-in-charge of the tent hospital set up in the grounds of the National Stadium. Although this did not give him any privileges as a prisoner, his being able to assist in the hospital did enable him to see what was going on in the camp. In this paper Dr fadresic describes his duties there and comments on the conditions and suffering he witnessed but could do little about.

Since being exiled from Chile Dr Fadresic continues to encourage everyone but particularly members of the medical profession to do all they can to gain worldwide support for the moral rejection of all forms of torture in all circumstances.

Medicine has been defined as a learned profession deeply rooted in a number of sciences and charged with the obligation to apply them for the benefit of man. ${ }^{1}$ One could hardly think of a stronger antithesis to its aims than torture. Yet the position of doctors towards torture varies widely. Torture is still today, unfortunately, a widespread practice in many countries and it is done not only with the complicity of policemen and military interrogators, but also of other professionals such as judges, lawyers, doctors and nurses.

I had in Chile the sad opportunity to live an experience which showed me some of the different positions that my own colleagues took when facing the problem and it makes me think there is an urgent need to clarify the views of the profession in this matter.

\section{Background}

My experience happened in Chile in 1973. Chile as a Latin American country was unique in enjoying an almost uninterrupted democracy since its independence more than a century and a half ago. On the II September 1973, a military coup put an end to democratic life and started one of the most cruel dictatorships in the history of Latin America. In the following months many thousands were killed; prolonged imprisonment without charges or trials, and torture became common practice; political assassinations have repeatedly been confirmed inside and outside the country; and, in recent years, 'disappearances' of individuals have come to constitute the most severe form of repression. ${ }^{2}$ About a million Chileans - 10 per cent of the total population - now live in exile.
Arrest and detention

One week after the coup, on the 18 September, whicht happens to be the National Day and a holiday, threg్ men knocked at the door of my house at lunchtime One of them in a rather polite manner addressed mo saying that he was a member of the Security Police and that they wanted me for a short interrogation. The other man was carrying an automatic machine gun The third was the driver. They took me in a car to the National Stadium, which a couple of days earlier had been opened as a concentration camp. I remained theres for 5 I days. I never received any explanation as to wh I was arrested. After three or four weeks I was interro gated by an Air Force officer and at the end of my sta in the Stadium I was informed that there were n\& charges against me but that I would not be allowed t $\vec{D}$ be free in the country, so I had to go into exile. ${ }_{0}^{\circ}{ }^{\circ}$

At the time I was detained I was working in the University of Chile, the State University foundesid 1843, where I was a Professor of Medicine and where had been the Dean of the Medical Faculty from 1968 to 1972. During the period I was in office, the Facult had given support to President Allende's Health Prơ gramme, developing new teaching hospitals and med $\vec{B}$ cal schools to increase the enrolment of medical students as there was a critical shortage of physicians if the country. The University had now been taken over and an Air Force general had been placed as the Rectos (Vice-Chancellor). I was informed that I was dismisseg from my post and that no questions were allowed. 3

At the beginning of my stay in the National Stadium I was approached by a military doctor who was in charge of the tent hospital set up in the grounds of the Stadium for the prisoners. He told me that he had nothing to do with what was going on in the countryo that he was there to carry out his professional duties a military doctor and that he was finding himseff unable to cope with the medical problems. He asked me whether I would be willing to help in providing caref to the prisoners. I accepted and this gave me the oppof tunity to learn something of what was going on in the camp.

There was at the time an epidemic of influenz among the prisoners and countless cases of bronchitis, pneumonia and broncho-pneumonia and several ouf breaks of lice infestations which required repeated die infection of clothes and blankets. Gastroenteritis ang diarrhoea were common. Some individuals were sup fering from chronic conditions which require 
attention such as epilepsy, gastro-duodenal ulcers, pulmonary tuberculosis and diabetes mellitus.

I received the same treatment as the other prisoners. We slept on the floor with one blanket per prisoner; some of us were accommodated in the changing rooms used in better days by football players or athletes, others in the bathrooms and still others in open external corridors, exposed to the cold weather of the season. Temperatures during September in Chile can sometimes fall at night to zero degrees centigrade. We received one bowl of soup per day plus one cup of coffee and a piece of bread in the morning and another in the evening which we had to eat standing or sitting on the floor. I lost 15 pounds in weight.

There was no communication at all with our families or friends outside the Stadium and restricted communication among prisoners inside. Three days before the Stadium was cleared out by transferring the prisoners to another concentration camp specially built in the desert in the north of Chile, the remaining prisoners were allowed for the first and only time to receive the visit of one relative or friend. Many of the soldiers and some of the officers seemed concerned with what was happening in the camp and appeared afraid to be seen in friendly conversation with prisoners. Some of them helped prisoners to hold clandestine contact by letter with their relatives or sent telephone messages to them. Sometimes we had the impression of being prisoners of prisoners. One young army officer committed suicide and the fact was not kept hidden by his colleagues. It was known throughout the camp. Two prisoners also committed suicide; one was a student and the other a Professor of Law.

\section{The ward round}

As part of my medical duties, I did a round twice daily in eight cells containing each 50 to 120 persons and in two very large corridors which were often full of people waiting to be classified and sent to other sectors of the Stadium. The whole of the area I was covering corresponded approximately to a quarter of the occupied capacity of the Stadium. Three other prisoner-doctors were on similar duties, each covering a quarter of the population. There was a rather quick turn-over of prisoners. I estimate that altogether some 15,000 individuals were sent to the National Stadium for periods ranging from three days to eight weeks. I would say that perhaps around half of them were treated with violence and that approximately 10 per cent were tortured. Foreign citizens may have been about 2,000 , mostly university students from other Latin American countries, including many medical students. There were approximately 500 women and some 60 youngsters under 16 years of age. The number of these youngsters was easy to verify since they were once called out over the loudspeakers to assemble in the central area.

Throughout the country several hundreds of doctors were arrested and taken to different prisoner camps. Doctors particularly persecuted were those who had refused to participate in the political strike against the Allende government just before the coup. At the National Stadium I met some 50 to 60 , including eight $\stackrel{\mathrm{W}}{=}$ women doctors. There were also many nurses and $\overline{\tilde{\phi}}$ other health personnel. All prisoners were interrogated at least once. Many of them were interrogated twices and some three or more times. Those who were tor-o tured were usually blindfolded and had their heado음 covered by a blanket.

During my medical rounds in the cells I was able to verify the results of many different types of torture. These included flagellation, beating with sticks or ${ }^{\text {e }}$ truncheons or butts of guns, kicking men in the geni-. tals, hanging the prisoner on a bar by the hands tied to $\overrightarrow{\vec{H}}$ the back, or with hands tied to ankles passing a baro behind the knees, application of electricity in the mouth, nipples or genitals or other parts of the body, burning with a lighter and with cigarette ends, mock executions, etc. Coming back from their interrogations, the prisoners showed the signs of the brutal $A$ physical punishment they had been submitted to:윽 burns, extensive bruising, lacerations, black eyes, ribfractures, contusions, enormous swelling of thes scrotum, etc. Several of them fell into shock. Otherso had uncontrollable tremor. I would usually take the ${ }_{3}^{\mathbb{D}}$ more severe cases to the tent hospital, but occasionally a prisoner would refuse to go to the tent hospital and prefer to remain in the cell under my care. Sevezako women were raped and I had direct evidence from tif of them, a Chilean university student and also an Uruguayan student, who were worried about the pos sibility of becoming pregnant or contracting a venereag disease. Among the prisoners there were pregnang women and a baby was born in the Stadium. SomeD prisoners were submitted to interrogation under pen $\overrightarrow{\vec{F}}$ tothal and several of them told me that they had seerf doctors and nurses participating in the interrogation.

\section{Doctors' attitudes}

One Brazilian prisoner presented with an intestina obstruction, which we diagnosed early and sent for immediate attention to the tent hospital. He was kept under observation there for two and a half days, during which he was radiologically studied at the main Military Hospital in the centre of the city. It was decided by the military doctors that he should be operated on in the tent hospital so the patient was brought back to the Stadium, operated on, and died during the operation. 5 was informed about this by the physician in charge of the tent hospital.

The military doctors who came to the tent hospital on duty did one day's work every fortnight. I presentee my complaints to them for the brutal way the prisonef? were being treated and for the tortures and asked theref to convey my concern to the medical and military authorities. Most of the doctors were young and some had been my students in the past. Several of then showed their sympathy for the tortured prisoners an $\$$ promised they would do something. Others, perhape the majority, pretended to ignore what they saw an 
appeared very much afraid of talking about it. A few of them justified what was happening on political grounds. Once, a young doctor replied to me in a rather aggressive manner: 'What do you expect? We are at war!' Taking for granted, obviously, that the practice of torture should be acceptable in case of war.

\section{Testimonies of torture}

Since I left Chile, many other testimonies of torture have been published such as the dramatic report by $\mathrm{Dr}$ Sheila Cassidy, ${ }^{3}$ which at the time led the British Government to recall the British Ambassador in Santiago, ${ }^{4}$ and multiple other cases denounced by Amnesty International. ${ }^{5}$

With the widespread use of torture throughout the world, medical personnel may become involved in various ways: as advisers in the use of drugs or the effectiveness of certain procedures, by ensuring that torture may continue, by covering up evidence of torture, by neglecting sick or injured prisoners and sometimes by participating themselves. ${ }^{6}$ Physicians employed by the Army or the Police may experience a conflict of conscience - between loyalty to the patient-prisoner or to the institution to which they belong.

It is difficult to define torture. Although infliction of pain is a basic element, the definition must also include the essential feature of mental or psychological stress. ${ }^{7}$ From the moral point of view the intention to break the will of the victim through degradation and destruction of the human personality is inadmissible. From the medical point of view it is to be considered that the latent emotional and physical effects of torture may be prolonged and deep and can lead to chronic irreversible somatic and psychic damage.

In December 1972, Amnesty International launched a worldwide Campaign for the Abolition of Torture. As part of this ongoing campaign, Amnesty International calls upon all professional individuals and organisations to subscribe to appropriate codes of conduct that would help to prevent the perversion of their professional skills in the service of torture, ${ }^{6}$ and proposes that the guiding principle for a medical code against torture could be the following rule from the International Code of Medical Ethics: "Under no circumstances is a doctor permitted to do anything that could weaken the physical or mental resistance of a human being, except for strictly therapeutic or prophylactic indications imposed in the interest of the patient". Based on a joint study carried out by the British and Irish Medical Associations, in 1975, the World Medical Association approved 'Guidelines for medical doctors concerning torture or punishment in relation to detention and imprisonment', known as the Declaration of Tokyo. ${ }^{8}$ It restates the doctor's duty to have nothing to do with torture: 'The doctor shall not countenance, condone or participate in the practice of torture or other forms of cruel, inhumane or degrading procedures, whatever the offence of which the victim of such procedures is suspected, accused or guilty, and whatever the victim's beliefs or motives, and in all situations, including armed conflict and civil strife.' A similar declaration was unanimously adopted by the United Nations Gen 7 eral Assembly in December 1975 as the Declaration on the Protection of All Persons from Torture and othere Cruel, Inhumane or Degrading Treatment or Punish ment. ${ }^{\circ}$

There is the hope that these guidelines may help doctors to clarify their views regarding torture. The new generation of doctors may be helped to a bette 5 understanding of the wide moral implications of their practice through the teaching of medical ethics as part్ of their undergraduate curriculum, which is becoming a trend in most medical schools in Europe and the USA. ${ }^{10-13}$ Medical codes of conduct should also help to prevent negligence and improper treatment in the care of prisoners and should allow doctors complete free dom to treat any person requiring medical care.

\section{Action for the future}

I think we are still far from succeeding in the abolition of torture. There are for instance countries that accept by law physical punishment and the death penalty byd stoning ${ }^{14}$ and many others that allow different forms of torture during interrogations. Yet I see no better ways of fighting this evil and inhumane practice than top persevere in the campaign to gain worldwide opinionfor the moral rejection of all forms of torture in albo circumstances.

I think in this campaign there is a special and signifi cant place for doctors. It has been considered a fun mental responsibility of the medical profession ton judge the moral and ethical propriety of each medicab act that affects another human being. I would explicitly add that this responsibility commits all medica 5 societies and medical associations to condemn the par 3 ticipation of any of their members in any way in the practice of torture.

\section{References}

${ }^{1}$ McDermott, W (1975). Medicine in modern society. Ing Beeson and McDermott, Textbook of medicine, I4th Edis tion, p 12. Philadelphia, London, Toronto. W B Saunders Co.

${ }^{2}$ Amnesty International Report 1978 (1979). London. Amnest International Publications.

${ }^{3}$ Cassidy, S (1977). Audacity to believe. London, W Collinș Sons \& Co.

${ }^{4}$ Fisk, R (1975). Mr Callaghan recalls ambassador over elec $N$ tric shock torture of Dr Cassidy. The Times, 3 IN December, London.

5Amnesty International Report 1977, pp 108-1 I I, London. Amnesty International Publications.

${ }^{6}$ Heijder, A and van Geuns, H (1976). Professional codes of ethics. London. Amnesty International Publications.

'Sagan, L A and Jonsen, A (1976). Medical ethics and torture. 0 The New England journal of medicine, 294, $\mathrm{pp}$ 1427-1430.

${ }^{8}$ Declaration of Tokyo (1975). World medical journal, $22, \frac{\mathrm{S}}{\mathrm{Q}}$ 87-90.

9United Nations General Assembly Resolution 3452 (XXX) 
of 9 December, 1975. Reprinted in Amnesty International Repont 1977, pp 42-44. London, Amnesty International Publications.

${ }^{10}$ Blomquist, C (1975). The teaching of medical ethics. Fournal of medical ethics, $\mathrm{I}, 96-98$.

"Veatch, R M and Fenner, D (1975). The teaching of medical ethics in the United States of America. Fournal of medical ethics, 1, 99-103.
${ }^{12}$ Jones, J S P and Metcalfe, D H H (1976). The teaching of medical ethics in the Nottingham Medical School. Fournal of medical ethics, 2, 83-86.

${ }^{13}$ Bank, S A and Vastyan, E A (1973). Humanistic studies in medical education. Foumal of medical education, 48 248-257.

${ }^{14}$ Amnesty International Report 1977, p 312 . London, Amnesty International Publications. 